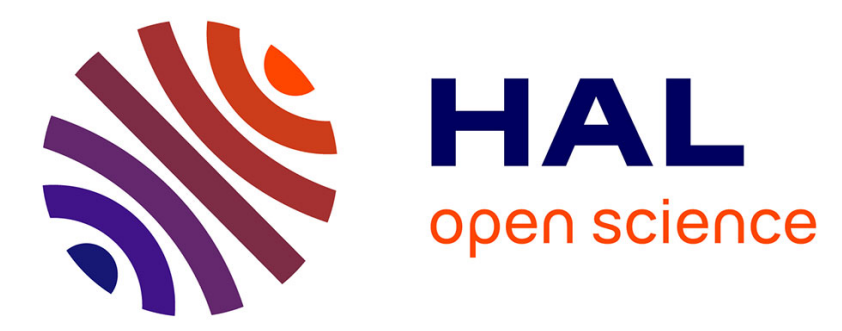

\title{
Problems in Adapting a Glucose-Oxidase Electrochemical Sensor into an Implantable Glucose-Sensing Device
}

\author{
Daniel R. Thevenot
}

\section{- To cite this version:}

Daniel R. Thevenot. Problems in Adapting a Glucose-Oxidase Electrochemical Sensor into an Implantable Glucose-Sensing Device. Diabetes Care, 1982, 5 (3), pp.184-189. hal-01083007

\section{HAL Id: hal-01083007 \\ https://hal-enpc.archives-ouvertes.fr/hal-01083007}

Submitted on 14 Nov 2014

HAL is a multi-disciplinary open access archive for the deposit and dissemination of scientific research documents, whether they are published or not. The documents may come from teaching and research institutions in France or abroad, or from public or private research centers.
L'archive ouverte pluridisciplinaire HAL, est destinée au dépôt et à la diffusion de documents scientifiques de niveau recherche, publiés ou non, émanant des établissements d'enseignement et de recherche français ou étrangers, des laboratoires publics ou privés.

\section{(c)(1)}

Distributed under a Creative Commons Attribution| 4.0 International License 


\title{
$P_{\text {roblems in Adapting a }}$ Glucose-Oxidase Electrochemical Sensor into an Implantable Glucose-Sensing Device
}

\author{
DANIEL R. THÉVENOT
}

Taking into account the analytic patterns of different types of glucose-oxidase electrochemical sensors, the specific problems which have to be solved for such a sensor to be implantable are outlined. Of particular interest is the lifetime of enzymatic membrane and the dependence of the sensor responses to oxygen concentration and hydrodynamics. DIABETES CARE 5: 184-189, MAY-JUNE 1982.

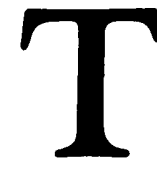

he continuous in vivo monitoring of the glucose concentration in blood should improve greatly treatment of diabetes. Such an implantable glucose sensor, needing neither blood withdrawal nor addition of reagent, should lead to an implantable artificial pancreas, i.e., a glucose-controlled insulin delivery system. ${ }^{1,2}$

The so-called enzyme electrodes, which in a small volume combine the enzyme reaction and electrochemical detection, present the highest selectivity and versatility for such reagentless metabolite determinations. ${ }^{2-4}$ Among them, glucose electrodes have been the most extensively studied and have led to, at least, two commercially available devices, i.e., Yellow Springs Instrument Model $23 \mathrm{~A}^{5}$ and Solea Tacussel model ENGL 1, ${ }^{6}$ based on the research work of Clark et al., ${ }^{7,8}$ and Thévenot, Coulet, Gautheron et al., ${ }^{9,10}$ respectively. All of these electrodes use $\beta$-D-glucose oxidation by dissolved oxygen in the presence of immobilized glucose oxidase (GOD), E.C. 1.1.3.4): they differ by their GOD immobilization technique and by the type of electrochemical detector pressed against the GOD membrane or film. This article analyzes the contribution of the different parts of the glucose-oxidase electrochemical sensor for the control of its analytical patterns and discusses the specific difficulties which have to be solved for such a sensor to be implantable.

\section{RESULTS}

Glucose-oxidase enzymatic membranes. In several commercially available glucose analyzers (Beckman, Technicon, Leeds and Northrup, Owens-Illinois) GOD is either a continuous flowthrough with sample and buffer or immobilized on a reaction loop or cartridge. ${ }^{11}$ For such an analyzer to become a reagentless specific electrode, GOD has to be immobilized as a thin layer pressed against the electrochemical de- tector. Since the pioneer work of Clark et al. ${ }^{7,8}$ and Updike et al. ${ }^{12,13}$ on glucose electrodes, five different types of immobilization procedures have been used and throughly studied (Table 1). Although similar immobilization procedures yield very different electrode stabilities, a few comments can be made on the published data: (1) the higher the temperature, the lower the stability and no long-term experiments have been performed at $37^{\circ} \mathrm{C},(2)$ GOD covalent binding, either by copolymerization or by reaction with activated membranes, yields the most stable glucose electrodes, (3) nonenzymatic proteins, such as albumin, gelatin, or collagen are used by most of the authors; indeed, such a proteinaceous environment seems to enhance GOD stability. ${ }^{14}$

In fact, the stability of such GOD-membranes should be examined from three different view points: mechanical, chemical and enzymatic (Table 2). A poor mechanical stability, encountered, for example, with thin copolymerized membranes, will affect the overall stability of the glucose electrode. Further difficulties appear for an implant: biocompatibility of the membrane and of hydrogen peroxide generation - an inactivator of many enzymes ${ }^{15}$, encapsulation by fibroblasts and giant cells, ${ }^{16}$ and finally, long-term stability at $37^{\circ} \mathrm{C}$ in human fluids or tissues.

Oxidation of glucose by dissolved oxygen is an irreversible process (Table 3): thus, on the contrary to sensors working at equilibrium, such as ion-selective electrodes, glucose electrodes reach a steady state in the presence of glucose. This steady state may be controlled either by the oxidation reaction with high temperature dependence $\left(6-10 \% /{ }^{\circ} \mathrm{C}\right)$ or by substrate diffusion with low temperature dependence (2$\left.4 \% /{ }^{\circ} \mathrm{C}\right) .{ }^{34,35,37,39,47,50}$

Under such heterogeneous kinetics, the glucose electrode consumes what it is supposed to monitor: this is a characteristic common to Clark's oxygen sensor. Whatever, the electrochemical detector associated to the GOD membrane, factors 
TABLE 1

Immobilization procedure of glucose oxidase and stability of glucose electrodes

\begin{tabular}{|c|c|c|c|c|}
\hline $\begin{array}{l}\text { Immobilization } \\
\text { procedure }\end{array}$ & Membrane material & $\begin{array}{l}\text { Storage } \\
\text { temp. }\left({ }^{\circ} \mathrm{C}\right)\end{array}$ & $\begin{array}{c}\text { Electrode } \\
\text { stability }\end{array}$ & Authors \\
\hline Solution entrapment & $\begin{array}{l}\text { Cellophane } \\
\text { Cellophane } \\
\text { Cellophane } \\
\text { Cellulose triacetate } \\
\text { Polyvinyl alcohol }\end{array}$ & $\begin{array}{r}38 \\
25 \\
\text { Un. }\end{array}$ & $\begin{array}{l}2 \mathrm{mo} \\
1-2 \mathrm{wk} \\
60 \mathrm{~h}\end{array}$ & $\begin{array}{l}\text { Clark et al. }{ }^{7, k, 17} \\
\text { Guilbault et al. }{ }^{18,19} \\
\text { Mindt et al. }{ }^{20,21}\end{array}$ \\
\hline Polyacrylamide gel & $\begin{array}{l}\text { Cellophane } \\
\text { No } \\
\text { Cellulose acetate }\end{array}$ & $\begin{array}{l}\text { Un. } \\
\text { Un. } \\
25 \\
4\end{array}$ & $\begin{array}{l}\text { Un. } \\
3 \text { wk } \\
8 \text { days } \\
3 \text { mo }\end{array}$ & $\begin{array}{l}\text { Mahenc et al. } .^{22} \\
\text { Updike et al. }{ }^{12,13} \\
\text { Notin et al. }{ }^{23}\end{array}$ \\
\hline & $\begin{array}{l}\text { Cellophane } \\
\text { Cellophane }\end{array}$ & $\begin{array}{l}25 \\
\text { Un. }\end{array}$ & $\begin{array}{l}6 \mathrm{mo} \\
1 \mathrm{wk}\end{array}$ & $\begin{array}{l}\text { Guilbault et al. }{ }^{18.24} \\
\text { Mosbach et al. }{ }^{23}\end{array}$ \\
\hline Copolymerization & $\begin{array}{l}\text { Polyacrylamide polyacrylic ac. } \\
\text { Albumin }+ \text { glutaraldehyde } \\
\text { Albumin }+ \text { glutaraldehyde } \\
\text { Albumin }+ \text { glutaraldehyde } \\
\text { Albumin }+ \text { glutaraldehyde } \\
\text { Collagen }+ \text { glutaraldehyde } \\
\text { Gelatin }+ \text { glutaraldehyde } \\
\text { Triazenylcellulose }\end{array}$ & $\begin{array}{r}25 \\
25 \\
\text { Un. } \\
\text { Un. } \\
37 \\
25 \\
4 \\
\text { Un. }\end{array}$ & $\begin{array}{l}10 \mathrm{mo} \\
4 \mathrm{mo} \\
2 \mathrm{mo} \\
3 \mathrm{wk} \\
2 \text { days } \\
6 \mathrm{mo} \\
7 \mathrm{mo} \\
2 \mathrm{wk}\end{array}$ & $\begin{array}{l}\text { Guilbault et al. }{ }^{18} \\
\text { Guilbault et al. }{ }^{26.27} \\
\text { Tranh Minh et al. }{ }^{28} \\
\text { Scheller et al. } .^{29.30} \\
\text { Wingard et al. }{ }^{31} \\
\text { Y.S.I. }{ }^{5.11} \\
\text { Thomas et al. }{ }^{32} \\
\text { Martiny et al. }{ }^{33}\end{array}$ \\
\hline $\begin{array}{l}\text { Covalently bound activated } \\
\text { metal }\end{array}$ & $\begin{array}{l}\text { Carbon paste: } \\
\text { Platinum } \\
\text { Graphite }\end{array}$ & 5 & $1-2$ mo & Wilson et al. ${ }^{34,35}$ \\
\hline & Glassy carbon & 4 & $1-2 w k$ & Thomas et al. ${ }^{36,54}$ \\
\hline $\begin{array}{l}\text { Covalently bound activated } \\
\text { membrane }\end{array}$ & $\begin{array}{l}\text { Teflon }+ \text { albumin }+ \text { formaldehyde } \\
\text { Collagen (acylazide) }\end{array}$ & $\begin{array}{r}37 \\
4 \\
20-30 \\
4\end{array}$ & $\begin{array}{l}2 \mathrm{wk} \\
6 \mathrm{mo} \\
6 \mathrm{mo} \\
30 \mathrm{mo}\end{array}$ & $\begin{array}{l}\text { Updike et al. }{ }^{37} \\
\text { Thévenot et al. }{ }^{9.10 .38}\end{array}$ \\
\hline
\end{tabular}

Un., unknown

TABLE 2

Stability of glucose-oxidase membranes

\begin{tabular}{l}
\hline \hline Factors affecting GOD membrane stability \\
Mechanical \\
Distance membrane/electrochemical detector \\
Permeability to glucose, oxygen, hydrogen peroxide \\
Rheological parameters \\
Chemical \\
Resistance towards hydrolases and proteases \\
Resistance to microbial degradation \\
Enzymatical \\
GOD thermal denaturation \\
GOD chemical denaturation \\
GOD washing out \\
Effect of microenvironment and hydrogen peroxide generation \\
Problems for implants \\
Biocompatibility \\
GOD membrane \\
Hydrogen peroxide generation \\
Implant encapsulation by fibroblasts and giant cells \\
Long-term mechanical, chemical and enzymatic stability of GOD mem- \\
branes at $37^{\circ} \mathrm{C}$, in whole blood, lymph or tissue \\
\hline
\end{tabular}

TABLE 3

Heterogeneous kinetics with glucose-oxidase membranes

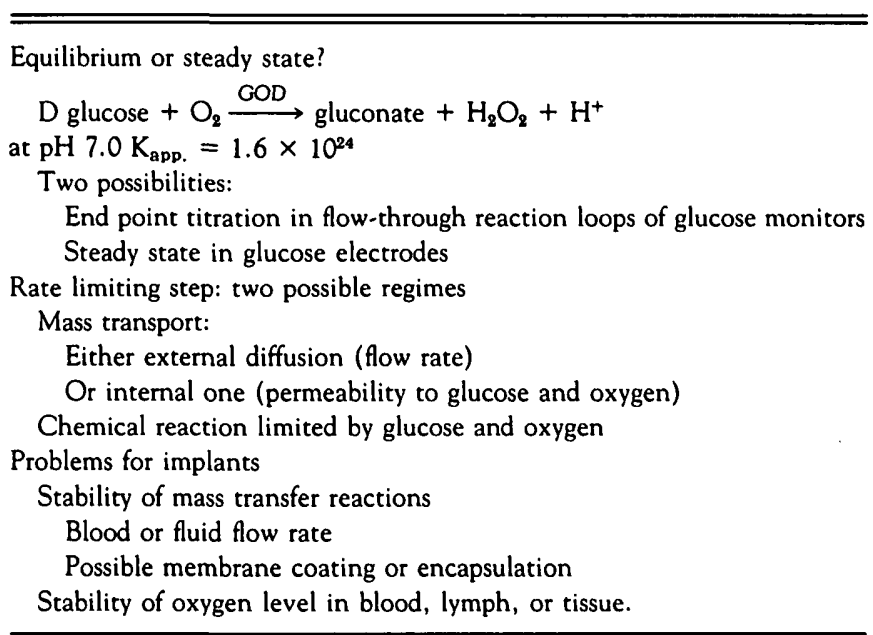


affecting external diffusion, i.e., fluid flow rate near the membrane, or internal diffusion, i.e., permeability to substrates, should be maintained constant as well as oxygen concentration level in or near the membrane. In the case of implantable glucose electrodes both conditions are difficult to realize: the latter may be indirectly and partially fulfilled by using a GOD membrane or an external membrane much more permeable to oxygen than to glucose ${ }^{\mathbf{4 0 , 4 1}}$ Table 3 outlines these considerations.

Electrochemical detectors in glucose electrodes. Oxidation of glucose in the presence of a GOD membrane may be monitored by the evolution of three reaction constituents, i.e., oxygen depletion, gluconic acid and hydrogen peroxide formation.

As shown in Table 4, detection of gluconic acid via a $\mathrm{pH}$ electrode seems to be the worst method resulting in poor sensitivity, selectivity and linearity of calibration curves.

Oxygen and hydrogen peroxide detection have both been used by many different research groups.
A Clark-type oxygen electrode is insensitive to all types of interfering substances, they are obviously very sensitive to variations of partial pressure of oxygen within the fluid in contact with the electrode, unless a differential system is used, i.e., two electrodes differing only by their GOD activity. ${ }^{12,13,37,44 a, 44 b}$ One should also remember that the signal related to glucose concentration is derived from the diminution of the initially high current of the oxygen electrode: such systems are less sensitive, unless a well-balanced differential device is used.

Amperometric detection of enzymatically generated hydrogen peroxide is probably the most developed system. It seems to be the only one present in commercially available glucose electrodes. ${ }^{5,6}$ Starting from a very low background current in the absence of glucose, this detector is very sensitive. The lowest detection limit reaches $10 \mathrm{nM}^{9,10}$ and a higher linear range has been obtained for the calibration curve, i.e., 2.3-4.5 concentration decades.

Since hydrogen peroxide amperometric detection is very

TABLE 4

Electrochemical detectors used in glucose electrodes

\begin{tabular}{|c|c|c|c|c|c|c|}
\hline \multirow[b]{2}{*}{ Electroch. detector } & \multirow[b]{2}{*}{ Added reactant } & \multicolumn{3}{|c|}{ Calibration curves } & \multirow[b]{2}{*}{$\begin{array}{l}\text { Precision } \\
\text { (\%) }\end{array}$} & \multirow[b]{2}{*}{ Authors } \\
\hline & & Type & $\begin{array}{l}\text { Detect } \\
\text { limit. }\end{array}$ & $\begin{array}{l}\text { (Nb. of conc. } \\
\text { decades) }\end{array}$ & & \\
\hline \multirow{2}{*}{$\begin{array}{l}\mathrm{pH} \\
\quad \text { (gluconic ac.) }\end{array}$} & No & $\mathrm{pH}-\mathrm{pH}_{0}$ vs. $\log \mathrm{C}$ & $\frac{1 \cap-3}{1 \cap-3}$ & Non lin. & Un. & Mosbach et al. ${ }^{25}$ \\
\hline & & pH-pH ${ }_{0}$ vs. C & $2 \times 10^{-3}$ & 0.5 & Un. & Enfors et al. ${ }^{45}$ \\
\hline \multirow{7}{*}{$\begin{array}{r}\text { Clark }\left(\mathrm{O}_{2}\right) \\
\text { (D) }\end{array}$} & No & $\mathrm{I}_{0}-\mathrm{I}$ vs. $\mathrm{C}$ & $10^{-4}$ & 2 & Un. & Clark et al. ${ }^{7}$ \\
\hline & No & $\mathrm{I}_{0}-\mathrm{I}$ vs. $\mathrm{C}$ & $10^{4}$ & 2 & $2-4$ & Updike et al. ${ }^{12,13,37}$ \\
\hline & No & $\mathrm{I}_{0}-\mathrm{I}$ vs. $\mathrm{C}$ & $2 \times 10^{-4}$ & 1.7 & Un. & Notin et al. ${ }^{23}$ \\
\hline & $\mathrm{O}_{2}$ & $I_{0}-I$ vs. $C$ & $2 \times 10^{-3}$ & 1 & 2 & Than Minh et al. ${ }^{28}$ \\
\hline & No & $\mathrm{I}_{0}-\mathrm{I}$ vs. $\mathrm{C}$ & or $10^{-3}$ & 0.5 & Un. & Thomas et al. ${ }^{\mathbf{4 2}}$ \\
\hline & No & {$\left[\frac{\mathrm{dl}}{\mathrm{dt}}\right]_{\max }^{\mathrm{vs} . \mathrm{C}}$} & $10^{-4}$ & Non lin. & $1-5$ & Thomas et al. ${ }^{32}$ \\
\hline & No & $\mathrm{I}_{0}-\mathrm{I}$ vs. $\mathrm{C}$ & $\begin{array}{l}5 \times 10^{-4} \\
\quad \text { or } 5 \times 10^{-3}\end{array}$ & 0.7 & Un. & Gondo et al. ${ }^{43}$ \\
\hline Galv. cell (D) & No & $\mathrm{I}_{0}-\mathrm{I}$ vs. $\mathrm{C}$ & $3 \times 10^{-3}$ & 0.5 & Un. & Bessman et al. ${ }^{44}$ \\
\hline $\begin{array}{l}\text { Pt cathode } \\
\qquad\left(\mathrm{O}_{2} \text { and } \mathrm{H}_{2} \mathrm{O}_{2}\right)\end{array}$ & No & $\mathrm{I}_{0}-\mathrm{I}$ vs $\mathrm{C}$ & $5 \times 10^{-5}$ & 1.3 & Un. & Guilbault et al. ${ }^{26}$ \\
\hline (D) & No & I vs. C & $10^{-4}$ & 2 & Un. & Clark et al. ${ }^{8}$ \\
\hline \multirow[t]{2}{*}{$\begin{array}{l}\text { Pt Anode } \\
\left(\mathrm{H}_{2} \mathrm{O}_{2}\right)\end{array}$} & No & {$\left[\frac{\mathrm{dI}}{\mathrm{dt}}\right] \begin{array}{l}\text { vs. C } \\
\max \end{array}$} & $5 \times 10^{-5}$ & 1.9 & 2 & Y.S.I. ${ }^{5,46}$ \\
\hline & No & I vs. C & $\begin{array}{l}5 \times 10^{-4} \\
\quad \text { or } 5 \times 10^{-3}\end{array}$ & 2 & 5 & Scheller et al. ${ }^{4,29,30}$ \\
\hline \multirow[t]{2}{*}{ (D) } & No & I vs. C & $10^{-5}$ & 1.5 & Un. & Martiny et al. ${ }^{33}$ \\
\hline & No & I vs. C & $5 \times 10^{-4}$ & 2.3 & Un. & Guilbault et al. ${ }^{\mathbf{1 8 , 2 7}}$ \\
\hline \multirow[t]{2}{*}{ (D) } & No & I vs. C & $10^{-8}$ & 4.5 & $2-4$ & Thévenot et al. ${ }^{9,10}$ \\
\hline & No & I vs. C & $10^{-7}$ & 4 & $1-3$ & Solea Tacussel ${ }^{6}$ \\
\hline \multirow{2}{*}{$\begin{array}{l}\text { Pt Cath. } \\
\qquad\left(\mathrm{I}_{2} \text { for } \mathrm{H}_{2} \mathrm{O}_{2}\right)\end{array}$} & $\mathrm{I}^{-}$ & I vs. C & $10^{-4}$ & 1.2 & Un. & Mell et al. ${ }^{47,48}$ \\
\hline & $+\mathrm{Mo}(\mathrm{VI})$ & & $5 \times 10^{-4}$ & 0.9 & 2 & Wilson et al. ${ }^{34,35}$ \\
\hline $\begin{array}{l}\text { I.S.E. } \\
\qquad\left(\mathrm{I}^{-} \text {for } \mathrm{H}_{2} \mathrm{O}_{2}\right)\end{array}$ & $\begin{array}{c}\mathrm{I}^{-} \\
+ \text {peroxidase }\end{array}$ & $E$ vs. $\log C$ & $3 \times 10^{-4}$ & 0.5 & Un. & Guilbault et al. ${ }^{19}$ \\
\hline \multirow{3}{*}{$\begin{array}{l}\mathrm{Pt} \text { anode } \\
\qquad\left(\mathrm{O}_{2} \text { replacement }\right)\end{array}$} & quinone & I vs. C & $10^{-3}$ & 1.3 & 6 & Williams et al. ${ }^{49}$ \\
\hline & 2-6 DPIP & I vs. C & Un. & Un. & Un. & Mindt et al. ${ }^{20,21}$ \\
\hline & $\mathrm{Fe}(\mathrm{CN})_{6}^{3-}$ & I vs. C & $5 \times 10^{-4}$ & 1.1 & 5 & Mahenc et al. ${ }^{22}$ \\
\hline
\end{tabular}

Un., unknown; (D) differential detector; 2-6 DPIP, 2-6 dichloroindophenol. 
sensitive to naturally occurring electron donors, such as ascorbate, urate, tyrosine, etc., two methods have been developed to increase the selectivity of the glucose electrode towards such electrochemically interfering substances. Either the response is compensated by a nonenzymatic detector $^{8-10,33}$ or the platinum anode is covered by a cellulose acetate membrane with pores that will exclude ascorbate and most other potential interfering substances in 14 times diluted blood samples. ${ }^{5}$

Table 4 also presents a few other electrochemical detectors either detecting indirectly hydrogen peroxide by its reaction with added iodine, ${ }^{19,34,35,47,48}$ or replacing oxygen by other electron acceptors and detecting amperometrically their reaction products. ${ }^{20-22.49}$ All these alternatives present no interest for in vivo measurements since they require addition exagenous reagents.

Because of its lower dependence on oxygen concentration in the sample, we favor hydrogen peroxide detection in potentially implantable glucose electrodes. A.s seen above, either a selection or a compensation of interfering electron donors have to be realized. Furthermore, as glucose levels in blood, i.e., $50-1000 \mathrm{mg} / \mathrm{dl}$ or $3-55 \mathrm{mM}$, are higher than the apparent $K_{M}$ or $S_{0.5}$ of typical glucose oxidase membranes, i.e., 4-10 $\mathrm{mM},{ }^{34,47,51}$ calibration curves may not be linear. If one accepts a decrease of the electrode sensitivity, these calibration curves can become linear in a much higher concentration range, if an external diffusion barrier to glucose is placed in front of the GOD membrane. ${ }^{4}$

\section{DISCUSSION}

Taking into account the stability, selectivity, sensitivity, and linearity of glucose-oxidase electrochemical sensors, in vitro determinations of glucose seem relatively easy to perform with a $2-5 \%$ precision. If such a sensor is to be implanted into a blood vessel or in tissue, a large number of problems arise and some of them are not yet solved. Indeed, besides the general problem of implanting a physico-chemical sensor ${ }^{16}$ that generates hydrogen percoxide, ${ }^{15}$ there are many difficulties to take into account: (1) GOD membranes should be resistant to physical, chemical, and enzymatic denaturation for several weeks if not months of implantation at $37^{\circ} \mathrm{C},(2)$ hydrodynamic properties of the membrane and of the membrane-solution interface, i.e., the fluid flow rate should not vary in the electrode vicinity, (3) electrode response should be independent of the variations of oxygen level inside the fluid: permeability of oxygen in the membrane should be higher than for glucose, (4) electrode response should vary linearly with glucose level in the hyperand hypoglycemia range, i.e., from 20 to $2000 \mathrm{mg} / \mathrm{dl}$ or $1-100 \mathrm{mM}$, and have a low temperature dependence $\left(2-4 \% /{ }^{\circ} \mathrm{C}\right),(5)$ if amperometric detection is used, which can be appreciated for its simplicity, sensitivity and proportionality between signal and glucose concentration in a very large range, ${ }^{9,10}$ the electrode response should be made insensitive to endogenous electroactive electron donors by using a differencial device, i.e., a compensating electrode ${ }^{8-10}$ (6) the whole system, membrane plus detector, should require minimal calibration and zero adjustment, (7) finally, the scaling down of the glucose electrode should not modify the geometrical, physical, and enzymatic characteristics which control its analytical properties.

A possible strategy for solving most of these problems consists in the detailed study of the properties of the GOD membrane either freely stirred or mounted on the electrochemical detector. In a previous paper, we have presented a simple device for monitoring the various hydrogen peroxide fluxes generated by the GOD membrane or flowing through it. ${ }^{51}$ Following Wilson' ${ }^{34,35}$ or Gough's $\mathrm{s}^{40,52}$ approach to such heterogeneous kinetics, the influence of hydrodynamics should be carefully studied.

Last but not least one should pay special attention to the overall stability of the glucose electrode and especially of its GOD membrane, taking into account the relations hetween GOD stability, nature of the membrane and the way (GOD) has been coupled. This is obviously an acute problem if the glucose electrode is to be implanted for more than 24-48 $\mathrm{h}$. Much improvement has been made in the last decade, ${ }^{53}$ hut still several laboratories are active in that field.

From the Laboratoire de Bioélectrochimie et d'Analyse du Milieu, UER de Sciences, Université Paris Val de Marne, Avenue du General de Gaulle, F. 94010 Creteil Cédex, France.

Address reprint requests to Daniel $R$. Thévenot at the above address.

\section{REFERENCES}

${ }^{1}$ Albisser, A. M., Leibel, B. S., Zingg, W., Botz, C. K., Marliss, E. B., Denoga, A., and Zinman, B.: The development of an artificial endocrine pancreas and its application in research and clinical investigation. Horm. Metab. Res. (Suppl.) 7: 87-92, 1977.

${ }^{2}$ Gough, D. A., Aisenberg, S., Colton, C. K., (Siner, J., and Soeldner, J. S.: The status of electrochemical sensors for in vivo glucose monitoring. Horm. Metab. Res. (Suppl.) 7: 10-21, 1977.

${ }^{3}$ Guilbault, G. G.: Enzyme electrode probes. In Immobilized Enzymes, Antigens, Antibodies and Peptides. Weetall, H. H., Ed. New York, Marcel Dekker, 1975, pp. 293-417.

${ }^{4}$ Scheller, F., and Pfeiffer, D.: Enzymelektroden. Zeitschrift für Chemie 2: 50-57, 1978.

${ }^{5}$ Yellow Springs Instrument Co.: Instruction manual Y.S.I. model 23A, 1975.

${ }^{6}$ Solea Tacussel: Provisional notice on Solea Engl. 1, 1980.

${ }^{7}$ Clark, L. C., and Lyons, C.: Electrode systems for continuous monitoring in cardiovascular surgery. Ann. N. Y. Acad. Sci. 102: $29-45,1962$.

${ }^{8}$ Clark, L. C.: Membrane polarographic electrode system and method with electrochemical compensation. U.S. Patent 3, 539, 455, Nov. 10, 1970.

${ }^{9}$ Thévenot, D. R., Coulet, P. R., Sternberg, R., and (Bautheron, D. C.: A highly sensitive glucose electrode using glucose oxidase collagen film. Bioelectrochem. Bioenerg. 5: 548-53, 1978.

${ }^{10}$ Thévenot, D. R., Sternberg, R., Coulet, P. R., Laurent, J., and Gautheron, D. C. Enzyme collagen membrane for electrochemical determination of glucose. Anal. Chem. 51: 96100, 1979. 
${ }^{11}$ Keyes, M. H., Semersky, F. E., and Gray, D. N.: Glucose analysis utilizing immobilized enzymes. Enzyme Microbiol. Technol. 1: (4) 91-.94, 1979.

12 Updike, S. J., and Hicks, G. P.: The enzyme electrode. Nature 214: 986-88, 1967.

${ }^{13}$ Hicks, G. P., and Updike, S. J., U.S. Patent 3, 542, 622, Nov. 24,1970

${ }^{14}$ Coulet, P. R., and Gautheron, D. C.: Resistance to deactivation of enzyme-collagen membrane. Biochimie 62: 543-47, 1980.

${ }^{15}$ Cho, Y. K., and Bailey, J. E.: Enzyme immobilization on activated carbon: alleviation of enzyme deactivation by hydrogen peroxide. Biotechnol. Bioenerg. 19: 185-98, 1977.

${ }^{16}$ Woodward, S. C.: How fibroblasts and giant cells encapsulate implants: considerations in design of glucose sensors. Diabetes Care 5: $278-81,1982$.

${ }^{17}$ Clark, L. C., Jr, and Clark, E. W.: Differential anodic enzyme polarography for the measurement of glucose. Adv. Exp. Med. Biol. USA 37A: 127-33, 1973.

${ }^{18}$ Guilbault, G. G., and Lubrano, G. J.: An enzyme electrode for the amperometric determination of glucose. Anal. Chim. Acta 64 : $439-45,1973$

${ }^{19}$ Nagy, G., von Storp, L. H., and Guilbault, G. G.: Enzyme electrode for glucose based on an iodine membrane sensor. Anal. Chim. Acta 66: (3) 443-55, 1973.

${ }^{20}$ Mindt, W., Racine, Ph., and Schlaepfer, P.: Sensoren für Lactat und Glucose. Ber. Busenges. Phys. Chem. 77 (10-11): 804$808,1973$.

${ }^{21}$ Mindt, W., Racine, Ph., and Schlaepfer, P.: Enzymelektrode. Ger. Offen. 2,243,962, March 15, 1973.

${ }^{22}$ Mahenc, J., and Aussaresses, H.: Electrode à enzyme spécifique du glucose basée sur a la détection ampérométrique de l'héxacyanoferrate II.C. R. Acad. Sci. Paris 289: (14) ser. C, 357-359, 1979.

${ }^{23}$ Notin, M., Guillien, R., and Nabet, P.: Le dosage du glucose sanguin à l'aide d'une électrode à enzyme. Ann. Biol. Clin. 30 (2): 193-97, 1972.

${ }^{24}$ Guilbault, G. G., and Lubrano, G. J.: Enzyme electrode for glucose. Ann. Chim. Acta 60: 254-56, 1972.

${ }^{25}$ Nilson, H., Akerlind, A. C., and Mosbach, K.: Determination of glucose, urea and penicillin using enzyme-pH electrodes. Biochim. Biophys. Acta, 320, 529-534 (1973)

${ }^{26}$ Nanjo, M., and Guilbault, G. G.: Enzyme electrode for Lamino acids and glucose. Anal. Chim. Acta 73 (2): 367-73, 1974.

${ }^{27}$ Lubrano, G. J., and Guilbault, G. G.: Glucose and L-amino acid electrodes based on enzyme membranes. Anal. Chim. Acta 97: 229-36, 1978.

${ }^{28}$ Tran-Minh, C., and Broun, G.: Construction and study of electrodes using cross-linked enzymes. Anal. Chem. 47: 1359-64, 1975.

${ }^{29}$ Scheller, F., Pfeiffer, D., Seyer, I., Prumke, H. J., and Janchen, M.: Enzymelektrode zur Bestimmung von Glucose. DDR Patent 123-125, Nov. 20, 1976

${ }^{30}$ Scheller, F., Janchen, M., Pfeiffer, D., Seyer, I., and Muller, K.: Enzymelektrode zum Nachweis von Glucose. Z. Med. LaborDiagn. 18: 312-16, 1977.

${ }^{31}$ Wingard, L. B., Schiller, J. G., Wolfson, S. K., Jr, Liu, C. C., Drash, A. L., and Yao, S. J.: Immobilized enzyme electrodes for the potentiometric measurement of glucose concentration: immobilization techniques and materials. J. Biomed. Material Res. 13: 921-35, 1979.

${ }^{32}$ Romette, J. L., Froment, B., and Thomas, D.: Glucose-oxidase electrode. Measurements of glucose in samples exhibiting high variability in oxygen content. Clin. Chim. Acta 95: 249-53, 1979.
${ }^{33}$ Martiny, S. C., and Jensen, O. J.: An enzyme electrode based on immobilized glucose oxidase. In lon and Enzyme Electrodes in Biology and Medicine. Kessler, M., Clark, L. C., Lubbers, D. W., Silver, I. A., and Simon, W., Ed. Munich, Urban and Schwarzenberg, 1976, pp. 198-99.

${ }^{34}$ Shu, F. R., and Wilson, G. S.: Rotating ring-disk enzyme electrode for surface catalysis studies. Anal. Chem. 48: 1679-86, 1976.

${ }^{35}$ Kamin, R., and Wilson, G. S.: Rotating ring-disk enzyme electrode for biocatalysis kinetic studies and characterization of the immobilized enzyme layer. Anal. Chem. 52: 1198-1205, 1980.

${ }^{36}$ Bourdillon, C., Bourgeois, J. P., and Thomas, D.: Chemically modified electrodes bearing grafted enzymes. Biotechnol. Bioeng. 21: $1877-79,1979$.

${ }^{37}$ Updike, S. J., Shults, M. C., and Busby, M.: Continuous glucose monitor based on an immobilized enzyme electrode detector. J. Lab. Clin. Med. 93: 518-27, 1979.

${ }^{38}$ Thévenot, D. R., Stemberg, R., and Coulet, P. R.: A glucose electrode using high stability glucose oxidase collagen membranes. Diabetes Care 5: 203-206, 1982.

39 Thévenot, D. R., and Sternberg, R.: Phénomènes limitants dans les électrodes à enzymes. Communication at "Journées d'Electrochimie", Strasbourg, 1979.

${ }^{40}$ Gough, D. A., Leypoldt, J. K., and Armour, J. C.: Progress toward a potentially implantable enzyme-based glucose sensor. Diabetes Care 5: 190-98, 1982.

${ }^{41}$ Updike, S. J., Shults, M., and Ekman, B.: Implanting the glucose enzyme electrode: progress, problems, and alternative solutions. Diabetes Care 5: 207-212, 1982.

${ }^{42}$ Cordonnier, M., Lawny, F., Chapot, D., and Thomas, D.: Magnetic enzyme membranes as active elements of electrochemical sensors. Lactose, saccharose, maltose, bienzyme electrodes. FEBS Lett. 59: 263-67, 1975.

${ }^{43}$ Gondo, S., Morishita, M., and Osaki, T.: Improvement of glucose sensor performance with immobilized glucose oxidase-glucose isomerase system. Biotechnol. Bioeng. 22: 1287-91, 1980.

${ }^{44 a}$ Layne, E. C., Schultz, R. D., Bessman, S. P., Thomas, L. J., Slama, G., and Sayler, D. F.: Continuous extracorporeal monitoring of animal blood using the glucose electrode. Diabetes 25: 81$89,1976$.

${ }^{44 b}$ Bessman, S. P., and Schultz, R. D.: Prototype glucoseoxygen sensor for the artificial pancreas. Trans. Am. Soc. Artif. Int. Organs 19: 361-64, 1973.

${ }^{45}$ Enfors, S. O., and Molin, N.: Response characteristics of pHbased enzyme electrodes for analysis of penicillin and glucose in fermentation broth. 1st Europ. Congress Biotechnology (Dechema) 2: $35-38,1978$

46 Potezny, N., Robson, J., and Fuller, B.: Testing of the Yellowsprings Instrument Model 23 AM glucose analyser. Report of Austr. Ass. of Clin. Bioch. Committee for Supply and Service of Equipment, Adelaide, South Australia, 1976.

${ }^{47}$ Mell, L. D., and Maloy, J. T.: A model for the amperometric enzyme electrode obtained through digital simulation and applied to the immobilized glucose oxidase system. Anal. Chem. 47: 299307, 1975.

${ }^{48}$ Mell, L. D., and Maloy, J. T.: Amperometric response enhancement of the immobilized glucose oxidase enzyme system. Anal. Chem. 48: 1597-1601, 1976.

49 Williams, D., Doig, A., and Korosi, A.: Electrochemical-enzymatic analysis of blood glucose and lactate. Anal. Chem. 42: $118-21,1970$

50 Racine, P., and Mindt, W.: On the role of substrate diffusion in enzyme electrodes. Experientia (Suppl.) 18: 525-34, 1971. 
51 Coulet, P. R., Sternberg, R., and Thévenot, D. R.: Electrochemical study of reactions at interfaces of glucose oxidase collagen membranes. Biochim. Biophys. Acta 612: 317--27, 1980.

52 Gough, D. A., and Leypoldt, J. K.: Membrane-covered, rotated disk electrode. Anal. Chem. 51: 439-44, 1979.
${ }^{53}$ Klibanov, A. M.: Enzyme stabilization by immobilization. Anal. Biochem. 93: 1-25, 1979.

${ }^{54}$ Bourdillon, C., Bourgeois, J. P., and Thomas, D.: Covalent linkage of glucose oxidase on modified glassy carbon electrodes. $\mathrm{Ki}$ netic phenomena. J. Am. Chem. Soc. 102: 4231-35, 1980. 